\title{
'Fit for Purpose': a cohort-centric approach to MOOC design
}

\section{Carolyn King, ${ }^{1}$ Kathleen Doherty, ${ }^{2}$ Jo-Anne Kelder, ${ }^{3}$ Fran McInerney, ${ }^{4}$ Justin Walls, ${ }^{5}$ Andrew Robinson ${ }^{6}$ and James Vickers ${ }^{7}$}

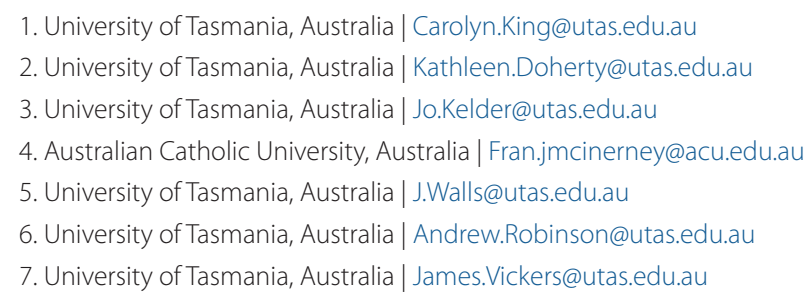

Submitted in: January 2014 Accepted in: June 2014 Published in: July 2014

\section{Recommended citation}

King, C., Doherty, K., Kelder, J., Mclnerney, F., Walls, J., Robinson, A. \& Vickers, J., (2014).'Fit for Purpose': a cohort-centric approach to MOOC design. RUSC. Universities and Knowledge Society Journal, 11(3). pp. 108-121. doi http://dx.doi.org/10.7238/rusc.v1 1i3.2090

\begin{abstract}
How do you design a quality massive open online course (MOOC) that will be 'fit for purpose'? The Understanding Dementia MOOC is an initiative of the University of Tasmania's Wicking Dementia Research and Education Centre (Wicking Centre). It is an outworking of institutional commitment to open education resources (OER) and open educational practices (OEP). This paper describes the development of the university's first MOOC, grounded in a philosophy that open learning design includes the criterion 'fit for purpose' and thus explicitly considers: the impetus for attempting a MOOC design; the goal (desired outcomes); the nature of the content; assumed capability thresholds of the intended cohort and; the technical and pedagogical design implications of the cohort's learning readiness. The development team used a design-based research approach underpinned by an evaluation framework. This paper will discuss the interplay of factors which influenced decision-making, including the nature of expert content (packaged by the development team, translated by students and applied in individual contexts), the intended scope of influence, barriers to access in open learning design, pedagogical commitments including adult learning theory, technological constraints, as well as external stakeholder requirements. The paper concludes with a discussion of the impact of maintaining a clear purpose in making a specific body of knowledge available as open content. In particular, we suggest that considerations of content access are not simply physical or technical,
\end{abstract}


but require tailoring the approach to threshold learning capabilities, as well as providing scaffolded content delivery such that individuals can translate their learning for their own contexts.

\section{Keywords}

open learning design, MOOC, open educational resource, open educational practice, Understanding Dementia

\section{«Adecuación al propósito»: un enfoque centrado en el colectivo de estudiantes para el diseño de un curso en línea masivo y abierto (MOOC)}

\section{Resumen}

¿Cómo se diseña un curso en línea masivo y abierto (MOOC) que sea «adecuado al propósito»? El curso MOOC Understanding Dementia (Comprender la demencia) es una iniciativa del Wicking Dementia Research and Education Centre (Wicking Centre) de la Universidad de Tasmania y hace realidad el compromiso de la institución con los recursos educativos abiertos (REA) y las prácticas educativas abiertas (PEA). El presente artículo describe el desarrollo del primer MOOC de esta universidad, basado en la filosofía de que el diseño del aprendizaje abierto debe incluir el criterio de «adecuación al propósito» y, por ende, tener en consideración lo siguiente: el impulso para decidirse a diseñar un MOOC; el objetivo (los resultados deseados); la naturaleza del contenido; los umbrales de capacidad asumida del colectivo de estudiantes; y las implicaciones en el diseño pedagógico y técnico de la predisposición al aprendizaje del colectivo de estudiantes en cuestión. El equipo de desarrollo del proyecto utilizó un enfoque de investigación basado en el diseño y apoyado en un marco de evaluación. Este artículo analiza la interacción de los factores que influyeron en la toma de decisiones, como la naturaleza del contenido experto (recopilado por el equipo de desarrollo, traducido por los estudiantes y aplicado a contextos individuales), el ámbito de influencia perseguido, las barreras al acceso en el diseño del aprendizaje abierto, los compromisos pedagógicos (incluida la teoría del aprendizaje de adultos), las limitaciones tecnológicas, así como los requerimientos de otras partes interesadas externas. El artículo concluye analizando el impacto que supone mantener un propósito claro al poner a disposición un cuerpo específico de conocimientos como contenido abierto. En particular, los autores sugieren que las consideraciones relativas al acceso a los contenidos no son simplemente físicas o técnicas, sino que es necesario adaptarlos a las capacidades de aprendizaje umbral, además de proporcionar una provisión de contenidos con apoyo escalonado de modo que los individuos puedan trasladar el aprendizaje a su propio contexto.

\section{Palabras clave}

diseño de aprendizaje abierto, MOOC, recurso educativo abierto, práctica educativa abierta, comprender la demencia 


\section{Introduction}

The University of Tasmania (UTAS) has an institutional objective to engage in Open Educational Practices (OEP), with commitments to social inclusion and community engagement. To this end, UTAS leads a nationally funded project with partner institutions, aimed at developing a community of scholarly practice in the field, as well as a repository of Open Educational Resources (OER) (http://www.teaching-learning.utas.edu.au/designing/openeducational-resources). In October 2012, the Deputy Vice Chancellor announced UTAS's intention to extend their OEP commitment to the massive open online course (MOOC) space, in the area of dementia. "We have taken a discrete and targeted approach in an area of community need that links genuinely leading edge research and teaching expertise" (Sadler, 2012). In terms of OEP, MOOCs represent both a strategic outworking of the use of existing OER, as well as a potential reservoir of new OER that can be incorporated into further learning (Daniel, 2012), where licensing permits.

The Wicking Dementia Research and Education Centre (Wicking Centre) is situated in the Faculty of Health at UTAS. The Wicking Centre's research focus spans the translational continuum from the biological basis of dementia to best models of care, while their educational objective is to generate knowledge that transforms practice. The sheer scale of the dementia issue: an ageing population worldwide, escalating numbers of people requiring dementia care and limited sources of evidence-based education to inform care practice, underpinned the Wicking Centre's vision for a new approach to dementia education. Traditional modes of delivery are unable to disseminate knowledge on a scale that matches international need. The Understanding Dementia MOOC is an outworking of both the institutional drivers in the open educational environment and the Wicking Centre's educational objectives.

In its first release, July 2013, the Understanding Dementia MOOC achieved a very high completion rate (39\%) compared with the average completion rates for MOOCs worldwide (4\%) (King, Robinson \&Vickers, 2014b). Completion rates in MOOCs depend on several variables, including the subject of the course, the way completion is measured, and closely related to this paper, the course design (Daniel, 2012). Furthermore, the course countered the 'typical' MOOC participant profile (Emanuel, 2013) by primarily attracting non-traditional learners, with 89\% women and $70 \%$ over the age of 40 (King et al., 2014b). Here, we report on the 'fit for purpose' design and evaluation features employed in the development of the Understanding Dementia MOOC. We suggest that key determinants of success include addressing the multi-faceted nature of 'accessibility' as a core concept, as well as tailoring the MOOC approach to the threshold learning capability of the target audience.

\section{Designing a MOOC}

\section{Open Learning Design Philosophy}

Open learning design in the current context refers to the processes involved in the planning, development and delivery of open education. The possession of expert knowledge and proven capabilities in translating that knowledge within traditional educational contexts (university, professional workplaces) is not necessarily sufficient to produce an effective learning design in the massive open education environments that MOOCs inhabit. MOOCs have been described as a model for delivering learning content online, with 'accessibility' being a key feature, such that they are open to 'virtually any person with no limit on attendance' (Connective Knowledge, 2011). The literature

RUSC VOL. 11 No 3 | Universitat Oberta de Catalunya and University of New England | Barcelona, July 2014

(a) King, K. Doherty, J.-A. Kelder, F. McInerney, J. Walls, A. Robinson and J. Vickers | @ FUOC, 2014 | 'Fit for Purpose': a cohort-centric approach to Mooc design 
provides well-documented issues with MOOC deliveries (Bady, 2013; Kolowich, 2013) and low completion rates (Parr, 2013). Additionally, reports that MOOCs are reinforcing the advantages of the 'haves' rather than educating the 'have-nots' (Emanuel, 2013; Graham, 2012) indicates that 'open' cannot be assumed to equate with 'accessible'. One explanation for low completion rates and skewed participant demographics is that the 'open' in MOOCs is flawed due to an implicit design assumption: that registrants are 'university ready', characterised by motivation and confidence to learn, ability to acquire academic knowledge and skills, as well as technical and social networking literacy and time to commit to study (Haggard, 2013; Smith, 2013). Here, we present evidence that a MOOC can reach non-traditional and disadvantaged learners (King et al., 2014b) when it is designed to address an acute social need (such as understanding dementia), explicitly responds to the educational requirements of the intended cohort and facilitates authentic learning with tangible outcomes.

To be truly an OER, a significant barrier to address in MOOC design is the capability thresholds of those who register (Haggard, 2013). The concept of open learning embedded in the philosophy underlying MOOCs is often inadequate because it assumes that merely providing high quality courses developed in tertiary education contexts will be accessible by anyone who is motivated and interested. A broader understanding of accessibility includes supporting people who are 'learning to learn', which implies that appropriate thresholding, particularly with reference to technical and academic literacy, is a key design consideration (Ausburn, 2004; Erickson \& Noonan, 2010). Indeed, it has been recognised that a supportive environment for, especially online, learners should not be an afterthought but, rather, integrated into the design process, determining what the course will become (Thorpe, 2002).

In order to design a course to benefit its intended audience, we determined that 'open' should include open to students with low threshold capability: students who would not qualify for access to tertiary education due to low academic (reading, writing, numeracy, technology, critical thinking) and technical literacy. We aimed to ensure 'fit' between the knowledge we wished to disseminate and the capabilities and needs of the learner. Such cohort analysis is in line with other instructional design methodologies (Nichols, 2010) and must be taken into consideration when designing MOOCs, particularly where the learner does not fit the traditional tertiary student profile. In recognition of increasing participation of part-time adult learners in online post-secondary education (Erickson \& Noonan, 2010), we used adult learning theory to guide our course learning design (Smith, 2013) which included both the learning activities and learning support provisions (Koper, 2006).

\section{'Fit for Purpose' Design Principle}

'Fit for purpose' is a concept that has been used in the past to define quality assurance in the construction of learning materials (Freeman, 1991). We used the concept of 'fit for purpose' in both our learning design and evaluation, to ensure the final MOOC design was aligned with our intended institutional and educational objectives, as well as the learning needs of our target audience. 'Fit for purpose', as a design principle, drove decision-making around the following key macro-level considerations:

1. institutional drivers for resourcing a MOOC;

2. educational objectives;

3. research objectives (educational research and dementia research);

4. assumed capability thresholds of the intended cohort and;

5. nature of the content.

RUSC VOL. 11 No 3 | Universitat Oberta de Catalunya and University of New England | Barcelona, July 2014 
The following sections discuss further the macro-level design considerations to ensure the MOOC was fit for each of these intended purposes.

\section{Institutional Drivers}

Institutional drivers to resource a MOOC as a strategic activity were linked to, but not limited to, reputation and serving public interest. The Understanding Dementia MOOC fitted the university strategic goal to engage in OEP and its commitments to social inclusion and community engagement. However, resource constraints meant that the MOOC initiative needed to be supported by a sustainable business model which balanced university resource investment and anticipated benefits, with effective risk-mitigation strategies such as piloting the content prior to full release. Given concerns about the resource implications of delivering MOOCs (Daniel, 2012; Mazoue, 2013), a further design consideration was the development of a pathway to financial sustainability for the MOOC offering. This was particularly relevant as we considered that our cohort would require a dedicated online teaching and technical presence (included a query triage, 2 part-time technical support personnel, a full time course coordinator and contributions from up to 11 additional content experts).

Participation in the MOOC was free, a free certificate of completion was provided and there were no summative assessments. Upon completion of the MOOC, students were offered the opportunity to enrol in units of UTAS's accredited online Bachelor of Dementia Care. Students could enter the Bachelor Course without completing the MOOC; however, to enable a supported articulation for non-traditional students, we created a new elective unit within the degree that was based upon the MOOC and enabled students to enter the formal tertiary learning environment via familiar content. .

\section{Educational Objectives}

For the Wicking Centre, the purpose of large scale educational delivery, as served by the concept of a MOOC, represented an opportunity to achieve globally significant educational outcomes whilst concurrently increasing the Wicking Centre's scope of influence. In the broadest sense, the educational aim was to facilitate improvement in quality of life for people with dementia, internationally, through improved knowledge and understanding of the condition. The link between carer education and quality of life for people with dementia (Mitchell, Kiely \& Hamel, 2004; Sampson, Ritchie, Lai, Raven \& Blanchard, 2005) indicated that the course needed to provide content of sufficient depth and breadth to be applicable to practice and also suitable to the learning capability of a carer group. Furthermore, some of the key characteristics of adult learners - the desire for autonomy, self-direction and an affinity for real-life learning (Knowles, Holton \& Swanson, 2011), as well as the potential to integrate study with work commitments (Smith, 2013-meant that this could be a powerful method of delivery despite the likelihood that the MOOC format may be a new style of learning for this group.

\section{Research Objectives (education research and dementia research)}

A design-based research approach was taken, underpinned by an educational evaluation framework, to ensure an evidence-based progression from pilot through to mature design (Kelder et al., 2013; King et al., 2013). Quantitative and qualitative data was collected for purposes of feedback for quality improvement and, longer term, evaluating

RUSC VOL. 11 No 3 | Universitat Oberta de Catalunya and University of New England | Barcelona, July 2014

(a) King, K. Doherty, J.-A. Kelder, F. McInerney, J. Walls, A. Robinson and J. Vickers | @ FUOC, 2014 | 'Fit for Purpose': a cohort-centric approach to Mooc design 
the MOOC in terms of impact and effectiveness. The course learning design and delivery evaluation was linked to the considerations arising from the 'fit for purpose' principle we adopted. The strategic research objectives included collecting information about international perspectives on dementia (King et al., 2013), as well as evaluating the MOOC in terms of whether the educational objectives were realised (to be reported elsewhere).

In order to evaluate the MOOC from the perspective of 'fit for purpose', we ensured that research tools were embedded into the course design to measure its effectiveness in relation to institutional, educational and educational research goals. Our intent was to generate a comprehensive data set which would form the basis of a research program in its own right. Data included: demographics of the MOOC participants (provided on registration), a Dementia Knowledge Assessment Tool (Toye, Popescus, Drake \& Lester,2013) that was administered pre- and post-exposure to content, comments on discussion forums, 'thought tree' (a novel discussion activity; Kelder et al., 2013) contributions and participants' reflective notes. A background survey was designed to assess motivations for registering to participate; feedback comments were invited from those who chose to exit early, and those who finished the course completed a final survey (broader research project of the Wicking Centre), which particularly strengthened our understanding of the educational needs of the cohort and their capacity to translate their learning into practice.

\section{Assumed Capability Thresholds of the Intended Cohort}

Decisions on'what' content and 'how'to package it into teaching-learning activities for effective learning experiences were framed by commitment to a cohort-centric pedagogy and use of digital technologies to serve learning. Laurillard's (2012) Conversational Framework provided the theoretical underpinning for content presentation. The Framework encompasses six types of learning through: acquisition, inquiry, practice, production, discussion and collaboration. The core purpose of online delivery of 'expert content' to a large, low-capability threshold cohort led to a focus on learning through acquisition (expert knowledge transmission), practice and production (King et al., 2014a).

The Wicking Centre's experience indicated that the characteristics of those in need of dementia education in the Australian context were likely to be consistent with the demographic features of the wider aged care workforce. Carers for people with dementia, both professional and family-based, are predominantly older females, often with limited higher education experience and computer literacy. Based on this knowledge and a soft release pilot of the course (Kelder et al., 2013), we assumed that the MOOC would attract people interested in the topic of dementia, motivated to engage in learning about dementia, but without appropriate levels of academic or technical literacy to engage in knowledge acquisition at a tertiary level. In this sense, we did not assume that registration to participate in the MOOC would imply'university ready.' The decision to design for low threshold capability affected pedagogical and technical choices related to both selecting content and presenting content. The educational goal was that students would be able to translate and apply the information appropriate to individual contexts, including professional practice.

\section{Nature of the Content}

Central to our design was the recruitment of a group of dementia experts, drawn from the Wicking Centre and associated academic and clinical environments. The twelve content experts included neuroscientists, social 
scientists, gerontologists, nurse psychologists, psychiatrists and behavioural management advisors. Importantly, we complemented academic and clinical experts with 'experience' experts directly affected by the condition (a family-based carer and a person with dementia). A core pedagogical consideration was to maintain a consistent narrative throughout, enabling students to build their knowledge around a few core concepts. The project leader had expertise in both neuroscience and education, and, through collaboration with an international expert in dementia care, was responsible for translating expert content for the cohort.

It has been demonstrated that completion rates improve for MOOCs of short duration (4-6 weeks) (Weller, 2013). However, a longer duration was necessary for our course to deliver sufficient expert content to enable carers to develop an evidence-based understanding that might inform their capacity to provide quality dementia care. We designed an 11-week course, with an introduction followed by three core content units: 'the brain', 'the diseases' and 'the person. The intention was to assist students to gradually build upon their knowledge by moving from a biological to a care focus. This was based on educational research showing that care strategies which achieve the greatest quality of life across the trajectory of the condition are those based on understanding dementia as an organic condition of the brain, characterised by progressive and degenerative processes that are ultimately terminal (Mitchell et al., 2009).

Content was delivered in a video interview format, conducted by an interviewer who assumed the role of 'naïve student' asking questions of the dementia expert. The interviewer assumed a knowledge threshold of the target cohort and guided the format and evolution of the conversation to achieve the intended learning outcomes. Content experts also participated in discussion forum interactions, including a dedicated forum within each unit of the course called 'ask an expert'. In the first full release, students could also email specific questions to the course developers, which were forwarded on to experts for comment. To maximize opportunities for participants to engage directly with experts, social media was used to inform students when MOOC dementia experts were presenting live information sessions in their local area.

\section{Learning Design}

The learning design for the Understanding Dementia MOOC was guided by the pedagogical and technical implications of the cohort's assumed low threshold capabilities and likely barriers to successfully engaging in tertiary level learning.

\section{Pedagogical Focus}

Laurillard's (2012) Conversational Framework highlights the affordances of various digital technologies that can serve different types of learning and can be incorporated into teaching-learning activities. The Framework links the design of teaching-learning activities to the desired response of students to build personal knowledge structures, as well as skill in using their knowledge (articulating and acting upon it). We considered carefully the affordances for learning that could be exploited by use of technologies, such as game-based learning tools, embedded in a MOOC design, and which learning types might be suited to the educational objectives and the cohort (Laurillard, 2012).

The 'massive' number of participants and minimal teacher presence inherent in a MOOC delivery constrain the possibility for student-to-teacher interactions. However, it has been suggested that sufficient levels of meaningful 
learning can be developed in online education, as long as one of the three forms of interaction (student-student; student-teacher; student-content) is at a very high level (Anderson, 2008). We have, therefore, focused on encouraging high quality student-content and student-student interactions. In terms of learning activities, there is limited scope for designing activities that engage the learner in learning through inquiry and collaboration. Therefore, our learning design focused on teaching-learning activities designed for 'learning through acquisition' (Laurillard, 2012; King et al., 2014a).

We provided opportunities for other types of learning (through practice, production and discussion) to enable students to build upon the expert content from their own context. Activities were designed to provide authentic learning opportunities such as care-based case studies and real-life examples that could be translated to care practice (Kellogg, 2013). This was important because many of the cohort participating in the Understanding Dementia MOOC were engaged in caring for someone with dementia, with an established context and pathway for applying what they were learning. We also recognised that one of the reasons that adults undertake learning in the first place is often to make sense of their own life experiences (Caffarella \& Barnett, 1994).

Recognising that adult learners enjoy flexible and self-directed methods of delivery Bordeau \& Bates, 1996), that can be adapted to their learning styles (Caffarella \& Barnett, 1994), many and varied methods of content delivery were employed to encourage active student engagement. Interviews with a broad range of content experts encouraged consideration of dementia from a variety of clinical, academic and personal perspectives. The interviews were coupled with illustrated text transcripts, embedded YouTube clips, case studies, puzzles, quizzes and visualization activities. We introduced novel role-play scenarios presented in cartoon format, with which students could interact by filling in speech bubbles to complete the scenario.

Experiential learning that capitalizes upon peoples' life experiences and prior knowledge is an important consideration when designing for adult learners (Knowles et al., 2011). We provided opportunities for experiential learning by embedding reflective note taking within the context of the content to enable students to record their own thoughts and ideas alongside the expert course content. Furthermore, experiential learning techniques also have the potential to break down barriers to engagement for adults returning to formal schooling who perceive themselves as having little to contribute (Caffarella \& Barnett, 1994). We created a unique activity, the 'thought tree', that enabled participants to realise their strengths as learners by drawing from the wealth of their life experiences (Kelder et al., 2013). Thought trees consisted of a sentence stem, for example, "My quality of life is enhanced by..." and participants completed the sentence, either anonymously or self-identified. Contributions by participants, served to 'grow' these concepts and enabled 'big' concepts like 'quality of life' or 'the function of the nervous system' to be captured more fully by being defined from a breadth of perspectives.

The MOOC design included elements to encourage and support students to establish a support network that extended beyond the learning experience. However, we recognized we could only facilitate and encourage, not construct such networks. Recognising that students from diverse cultural backgrounds were a valuable resource to demonstrate heterogeneity of perspectives, students were encouraged from the beginning to share their understandings and cultural perspectives (Anderson, 2008). Discussion forums were further used to encourage participants to share experiences in online learning, issues with technical literacy, as well as dementia care strategies and resource exchange. This 'surrogate' support environment was extended through social media by aligning the content being delivered with relevant posts on a MOOC-specific Facebook page.

RUSC VOL. 11 No 3 | Universitat Oberta de Catalunya and University of New England | Barcelona, July 2014 


\section{Technology Focus}

Technical design decisions regarding the digital technologies inherent in the open platform focused on optimising accessibility and scaffolding participant learning to overcome the well-known technical literacy barriers for many adult learners (Erickson \& Noonan, 2010). For example, the early focus was on assisting students to develop navigation skills through narrated orientation clips, help guides, and simple online activities. The goal of technical decisions was a learning environment that enabled the cohort to engage with the content in a variety of ways. Furthermore, a deliberate decision was made to avoid the need to utilise extraneous technologies that would add complexity but without improving the learning experience (Collins \& Berge, 2000).

We assumed threshold capabilities of the cohort as being more familiar with learning from traditional paperbased learning modalities, rather than an online environment. We thus created page templates for content delivery reminiscent of an interactive journal, instead of a series of web or content links. A graphic designer was employed to advise choices on colour palette, icon graphics for orienting participants to activities, font choices and background styles.

An example of using technology to create a 'fit for purpose' learning tool was the reflective writing feature called 'Your Notes'. This feature utilised a modification of the platform 'survey' tool and was implemented following a teaching activity where students were encouraged to actively engage with the content presented and integrate it with their own knowledge and practice. It was also intended to create a sense of ownership over the content. Students could record their own thoughts, ideas and reflections in response to scenarios, questions and visualisation exercises, and these were immediately integrated with the course content. At the course conclusion, the notes were downloadable as a collated 'record of learning'.

Digital technologies such as models and simulations, including 'serious games', facilitate student learning through practice (Laurillard, 2012; Grimley et al., 2012). We developed a software resource, Body Central, as a 'fit for purpose' digital technology tool to assist non-traditional learners to study nervous system anatomy. We developed our own software tailored to deliver the content for our cohort's threshold capability and enable them to reach the knowledge-based learning outcomes.

\section{Discussion and conclusions}

The Understanding Dementia MOOC attracted and retained the cohort for which it was designed. More than 9,267 people registered, the majority of these were female (89\%), $70 \%$ were more than 40 years old and only $17 \%$ of registrants held a degree beyond a Bachelor (King et al., 2014b). Our MOOC cohort differed starkly from that reported by Emmanuel (2013) —typically young, male, highly educated and employed. Furthermore, the 39\% completion rate for our 11-week course contrasts with the international average for MOOC completion, as well as the trend for decreasing completion with course duration (King et al., 2014b; Jordan, 2014; Parr, 2013).

The Understanding Dementia MOOC successfully contributed to UTAS's strategic commitment to engage in Open Educational Practices, enhancing its reputation and serving public interest. Our starting point was to challenge an assumption underlying the 'open' element in MOOCs and assert that a truly open learning design should take into account the capability thresholds of the intended cohort, the technical and pedagogical design implications of the cohort's learning readiness, as well as the educational theory surrounding adult learners. This approach produced 
a high quality learning experience that also supported institutional goals for enhanced reputation, social inclusion and community engagement, as well as enabling a business model for financial sustainability.

The concept of 'fit for purpose' was used to guide the learning design according to the following dimensions:

- clearly articulated objectives for each stakeholder group;

- provision of valuable (expert) content on a topic of broadly applicable interest;

- identification of the capability threshold of the intended audience; and

- consideration of the technical and pedagogical design implications of the cohort's learning readiness.

Most importantly for open courses, considerations of access are not simply physical or technical. The data demonstrates that to be truly accessible, design tailored for non-traditional adult learners with a low threshold of educational attainment (including technical literacy) will provide a scaffolded content delivery that enables individuals to understand and to translate their learning into practice, maintaining motivation to complete.

\section{References}

Anderson, T. (2008). Towards a theory of online learning. In T. Anderson \& F. Elloumi (eds.). Theory and practice of online learning, Chapter 2 (pp. 45-74). Edmonton, Canada: AU Press.

Ausburn, L. J. (2004). Course design elements most valued by adult learners in blended online education environments: an American perspective. Educational Media International, 41(4), 327-337. doi http://dx.doi. org/10.1080/0952398042000314820

Bady, A. (2013, May 15). The MOOC moment and the end of reform [Web log post]. Retrieved from http:// thenewinquiry.com/blogs/zunguzungu/the-mooc-moment-and-the-end-of-reform/

Bourdeau, J., \& Bates, A. (1996). Instructional design for distance learning. Journal of Science Education and Technology, 5(4), 267-283. doi http://dx.doi.org/10.1007/BF01677124

Caffarella, R. S., \& Barnett, B. G. (1994). Characteristics of adult learners and foundations of experiential learning. New directions for adult and continuing education, 1994(62), 29-42. doi http://dx.doi.org/10.1002/ace.36719946205

Collins, M., \& Berge, Z. L. (2000). Technological Minimalism in Distance Education. The Technology Source, November/ December.

Connective Knowledge (2011). Things you should know about MOOCs. Educause Learning Initiative, 1-2.

Daniel, J. (2012). Making Sense of MOOCs: Musings in a Maze of Myth, Paradox and Possibility. Journal of Interactive Media in Education. Retrieved from http://www-jime.open.ac.uk/jime/article/viewArticle/2012-18/html

Emanuel, E. J. (2013). Online education: MOOCs taken by educated few. Nature, 503(7476), 342-342. doi http://dx.doi. org/10.1038/503342a

Erickson, A. S. G., \& Noonan, P. M. (2010). Late-Career Adults in Online Education: A Rewarding Experience for Individuals Aged 50 to 65. MERLOT Journal of Online Learning and Teaching. 6(2), 388-397.

Freeman, R. (1991). Quality assurance in learning materials production. Open Learning: The Journal of Open, Distance and e-Learning, 6(3), 24-31. doi http://dx.doi.org/10.1080/0268051910060304

Graham, G. (2012, October 1). How the Embrace of MOOC's Could Hurt Middle America. Chronicle of Higher Education. Retrieved from http://chronicle.com/article/A-Pioneer-in-Online-Education/134654/ 
Grimley, M., Green, R., Nilsen, T., \& Thompson, D. (2012). Comparing Computer Game and Traditional Lecture Using Experience Ratings From High and Low Achieving Students. Australasian Journal of Educational Technology, 28(4), 619-638.

Haggard, S. (2013) The Maturing of the MOOC: literature review of massive open online courses and other forms of online distance learning. Department for Business, Innovation and Skills, UK Government. Retrieved from https:// www.gov.uk/government/publications/massive-open-online-courses-and-online-distance-learning-review

Jordan, K. (2014). MOOC Completion Rates:The Data. Retrieved from http://www.katyjordan.com/MOOCproject.html Kelder, J.-A., King, C., Carew, T., O’Reilly, J., Robinson, A., \& Vickers J. (2013). Evaluation of a MOOC pilot: impacts on pedagogical, technical and research design. Paper presented at the ascilite 2013, Sydney.

Kellogg, S. (2013). Online learning: How to make a MOOC. Nature, 499(7458), 369-371. doi http://dx.doi.org/10.1038/ nj7458-369a

King, C., Kelder, J.-A., Phillips, R., Mclnerney, F., Doherty, K., Walls, J., Robinson, A., \& Vickers, J. (2013). Something for Everyone: MOOC Design for Informing Dementia Education and Research. Paper presented at the European Conference in E-Learning (ECEL 2013), Sophia Antipolis, France. Retrieved from http://academic-conferences. org/ecel/ecel2013/ecel13-home.htm

King, C., Kelder, J.-A., Doherty, K., Phillips, R., Mclnerney, F., Walls, J., Robinson, A., \& Vickers, J. (2014a). Designing for Quality: The Understanding Dementia MOOC. Electronic Journal of e-Learning, Submitted.

King, C., Robinson, A. and Vickers, J. (2014b). Online education: Targeted MOOC captivates students. Nature, 505(7481), 26-26. doi http://dx.doi.org/10.1038/505026a

Knowles, M. S., Holton III, E. F., \& Swanson, R. A. (2011). The adult learner (7th ed.) London: Elsevier.

Kolowich,S.(2013, February4). Georgia techand Courseratry to recoverfrom MOOC stumble [Weblog post]. Retrieved from http://chronicle.com/blogs/wiredcampus/georgia-tech-and-coursera-try-to-recover-from-mooc-stumble/42167 Koper, R. (2006). Current Research in Learning Design, Educational Technology \& Society, 9(1), 13-22.

Laurillard, D. (2012). Teaching as a Design Science: building pedagogical patterns for learning and technology. New York: Routledge.

Mazoue, J. G. (2013). The MOOC Model: Challenging Traditional Education. Educause Review Online. Retrieved from http://www.educause.edu/ero/article/mooc-model-challenging-traditional-education

Mitchell, S., Kiely, D., \& Hamel, M. (2004). Dying with Advanced Dementia in the Nursing Home. Archives of Internal Medicine, 164(3), 321-6. doi http://dx.doi.org/10.1001/archinte.164.3.321

Mitchell, S. L., Teno, J. M., Kiely, D. K., Shaffer, M. L., Jones, R. N., Prigerson, H. G., Hamel, M. B. (2009). The clinical course of advanced dementia. New England Journal of Medicine, 361(16), 1529-1538. doi http://dx.doi.org/10.1056/ NEJMoa0902234

Nichols, M. (2010). No. 3: Designing for E-learning, 3, 1-31

Parr, C. (2013, May 9). MOOC completion rates 'below 7\%!. Times Higher Education. Retrieved from http://www. timeshighereducation.co.uk/news/mooc-completion-rates-below-7/2003710.article

Sadler, D. (2012). How Australian universities can play in the MOOCs market. The Conversation. Retrieved from https:// theconversation.com/how-australian-universities-can-play-in-the-moocs-market-9735

Sampson, E., Ritchie, C., Lai, R., Raven P., \& Blanchard, M. (2005) A Systematic Review of the Scientific Evidence for the Efficacy of a Palliative Care Approach in Advanced Dementia. International Psychogeriatrics, 17(1), 31-40. doi http://dx.doi.org/10.1017/S1041610205001018

RUSC VOL. 11 No 3 | Universitat Oberta de Catalunya and University of New England | Barcelona, July 2014 
Smith, V. C. (2013). The Adult Learner and MOOCs (New Horizons). Educause Review, 48(4), 54-55. Retrieved from https://net.educause.edu/ir/library/pdf/ERM1347.pdf

Thorpe, M. (2002). Rethinking learner support: The challenge of collaborative online learning. Open learning, 17(2), 105-119. doi http://dx.doi.org/10.1080/02680510220146887a

Toye, C., Popescus, A., Drake, J., \& Lester, L. (2007). Effectiveness of dementia specific carer education delivered throughout Western Australia: Early findings. Poster presentation at the Alzheimer's Australia National Conference in Perth, WA.

Weller, M. (2013, December 12). Completion data for MOOCs [Web log post]. Retrieved from http://nogoodreason. typepad.co.uk/no_good_reason/2013/12/completion-data-for-moocs.html

\section{About the authors}

\section{Carolyn King}

Carolyn.King@utas.edu.au

Wicking Dementia Research and Education Centre, University of Tasmania, Hobart, Australia

Dr Carolyn King is the Understanding Dementia Massive Open Online Course co-ordinator, a lecturer in the School of Medicine at the University of Tasmania, and a Wicking Centre Research Associate. She has a PhD in Neuroscience and her research interests include the biology of dementia, therapeutic approaches in dementia, as well as the scholarship of learning.

Wicking Dementia Research and Education Centre

University of Tasmania

Medical Science Building 1

17 Liverpool Street

Hobart 7001, Tasmania

Australia

\section{Kathleen Doherty}

Kathleen.Doherty@utas.edu.au

Faculty of Health, University of Tasmania, Hobart, Australia

Kathleen Doherty has a PhD (Medical Sciences) from the Australian National University and currently is a senior research fellow in the Faculty of Health, University of Tasmania. Her broad portfolio includes research performance and strategy, research capacity building and mentorship.

Faculty of Health

University of Tasmania

Medical Science Building 1

17 Liverpool Street

Hobart 7001, Tasmania

Australia

RUSC VOL. 11 No 3 | Universitat Oberta de Catalunya and University of New England | Barcelona, July 2014 


\section{Jo-Anne Kelder}

Jo.Kelder@utas.edu.au

Faculty of Health, University of Tasmania, Hobart, Australia

Jo-Anne Kelder has a PhD in Information Systems. Her research focus is the nexus between accreditation and practice, investigating the relations between organization-level accreditation based on high-level performance indicators and individual professional identities grounded in personal practice and membership of communities of practice. She is employed as Lecturer, Learning and Teaching Quality in the Quality Evaluation Learning and Teaching Unit, Faculty of Health, University of Tasmania.

Faculty of Health

University of Tasmania

Medical Science Building 1

17 Liverpool Street

Hobart 7001, Tasmania

Australia

\section{Fran Mclnerney}

Fran.jmcinerney@acu.edu.au

Australian Catholic University/Mercy Health, Melbourne, Australia

Fran Mclnerney is a registered nurse and a sociologist. She has a 30-year history in health practice, teaching and research, with a particular focus on aged and palliative care, especially as applied to people living with dementia. She has published and presented widely in these fields. Fran was the inaugural Chair of Aged Care at the Australian Catholic University from 2011-2014 and is currently Professor of Dementia Studies and Education in the Wicking Dementia Research and Education Centre at the University of Tasmania.

Australian Catholic University/Mercy Health

67 Cade Way

Parkville 3052, Victoria

Australia

Justin Walls

J.Walls@utas.edu.au

Faculty of Health, University of Tasmania, Hobart, Australia

Justin Walls is the Associate Dean Teaching and Learning and Head of the School of Medicine in the Faculty of Health at the University of Tasmania. Justin has research interests in basic physiology, particularly respiratory physiology, as well as projects in teaching and learning including inter-professional education, assessment standards, open learning and simulated learning environments.

Faculty of Health

University of Tasmania

Medical Science Building 1

17 Liverpool Street

Hobart 7001, Tasmania

Australia 


\author{
Andrew Robinson \\ Andrew.Robinson@utas.edu.au \\ Wicking Dementia Research and Education Centre, University of Tasmania, Hobart, Australia \\ School of Health Sciences, University of Tasmania, Hobart, Australia
}

Andrew Robinson is Professor of Aged Care Nursing, in the School Of Health Sciences and Co-Director, Wicking Dementia Research and Education Centre (WDREC), University of Tasmania. As Co-Director of WDREC, Andrew oversees projects that span translational health services research, clinical and biomedical research, and education and workforce capacity, to tackle the leading issues related to the increasing numbers of people with dementia.

Wicking Dementia Research and Education Centre

University of Tasmania

Medical Science Building 1

17 Liverpool Street

Hobart 7001, Tasmania

Australia.

\title{
James Vickers
}

James.Vickers@utas.edu.au

Wicking Dementia Research and Education Centre, University of Tasmania, Hobart, Australia

James Vickers holds the Chair of Pathology at the University of Tasmania and is also Deputy Dean of the Faculty of Health and Co-Director of the Wicking Dementia Research and Education Centre. His qualifications include a Bachelor of Science, $\mathrm{PhD}$ and Doctor of Science. He is also currently a board member of the Royal Hobart Hospital Research Foundation, Chair of the Scientific Panel for Alzheimer's Australia Dementia Research Foundation and the President of the Australasian Neuroscience Society. His research interests include Alzheimer's disease, traumatic brain injury and structural brain plasticity. He is also involved in projects related to health care services improvement.

Wicking Dementia Research and Education Centre

University of Tasmania

Medical Science Building 1

17 Liverpool Street

Hobart 7001, Tasmania

Australia

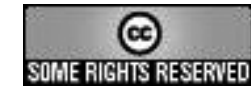

The texts published in this journal are - unless indicated otherwise - covered by the Creative Commons Spain Attribution 3.0 licence. You may copy, distribute, transmit and adapt the work, provided you attribute it (authorship, journal name, publisher) in the manner specified by the author(s) or licensor(s). The full text of the licence can be consulted here: <http://creativecommons.org/licenses/by/3.o/es/deed.en>

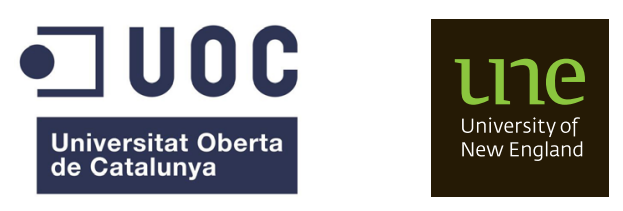

RUSC VOL. 11 No 3 | Universitat Oberta de Catalunya and University of New England | Barcelona, July 2014

@ King, K. Doherty, J.A. Kelder, F. Mclnerney, J. Walls, A. Robinson and J. Vickers | @ FUOC, 2014 | 'Fit for Purpose': a cohort-centric approach to MOoC design 